\title{
Gea
}

JURNAL PENDIDIKAN GEOGRAFI

\section{PERSEPSI MASYARAKAT PETANI TAMBAK TERHADAP KELESTARIAN HUTAN MANGROVE DI DESA PABEAN ILIR KECAMATAN PASEKAN KABUPATEN INDRAMAYU}

\author{
Sodikin \\ Program Magister Ilmu Lingkungan UNDIP Semarang \\ email: shodiq_cahbageur@yahoo.com
}

\begin{abstract}
ABSTRAK
Latar belakang penulis melakukan penelitian ini adalah adanya perbedaan persepsi masyrakat petani tambak terhadap kelestarian hutan mangrove baik dari segi teknis, ekonomi maupun sosial yang berpengaruh terhadap usaha kelestarian hutan mangrove di Desa Pabean Ilir. Tujuan yang ingin di capai dalam penelitian ini adalah mengidentifikasi kondisi hutan mangrove, kodisi sosial ekonomi masyarakat dan perbedaan persepsi masyarakat petani tambak terhadap kelestarian hutan mangrove.Metode yang digunakan dalam penelitian ini adalah metode deskriptif, dengan teknik pengumpulan data melalui observasi lapangan, studi kepustakaan, studi dokumentasi, dan wawancara. Populasi adalah semua penduduk yang ada di Desa Pabean Ilir yang berjumlah 6.367 jiwa. Sampel penelitian adalah petani tambak yang diambil secara random (acak) dengan jumlah sampel sebanyak 75 orang. Hasil yang diperoleh dari penelitian ini menunjukan bahwa secara umum kondisi fisik daearah penelitian sesuai untuk pertumbuhan hutan mangrove, kondisi sosial ekonomi masyarakat di daerah penelitian tergolong mempunyai tingkat pendidikan yang tidak begitu tinggi, dan masyarakat mempunyai persepsi bahwa secara ekonomi masyarakat memandang hutan mangrove sangat bermanfaat untuk tempat mencari ikan dan kepiting, secara teknis bermanfaat untuk mencegah terjadinya abrasi, sedangkan dari segi sosial masyarakat mempunyai persepsi bahwa hutan mangrove sangat bermanfaat untuk menambah keindahan pemandangan.

Kata kunci : persepsi, masyarakat, kelestarian, mangrove.
\end{abstract}

\section{PENDAHULUAN}

\section{Latar Belakang Masalah}

Indonesia merupakan negara kepulauan terbesar di dunia yang terdiri dari 17.508 pulau dengan garis pantai sepanjang $81.000 \mathrm{~km}$ Dahuri (1999:1). Wilayah pantai dan pesisir memiliki arti yang strategis karena merupakan wilayah interaksi/peralihan (interface) antara ekosistem darat dan laut yang memiliki sifat dan ciri yang unik, dan mengandung produksi biologi cukup besar serta jasa lingkungan lainnya. Kekayaan sumberdaya yang dimiliki wilayah tersebut menimbulkan daya tarik bagi berbagai pihak untuk memanfaatkan secara langsung atau untuk meregulasi pemanfaatannya karena secara sektoral memberikan sumbangan yang besar dalam kegiatan ekonomi misalnya pertambangan, perikanan, kehutanan, industri, pariwisata dan lain-lain. Wilayah pesisir mencakup beberapa ekosistem, salah satunya adalah ekosistem hutan mangrove. 
Perkembangan penduduk dengan tingkat kebutuhan yang makin meningkat, secara cepat telah mendegradasi hutan mangrove dan berusaha menggantikan lahan-lahan hutan mangrove dengan usaha lain yang lebih cepat " menguntungkan" dari segi finansial namun sebenarnya sangat merusak lingkungan. Pranawingtyas dalam Sudarso (2004 : 14) mengatakan bahwa kerusakan hutan mangrove di Indonesia sudah tergolong cukup parah yaitu sudah mencapai 68\% dan kawasan hutan mangrove di Pantai Utara Pulau Jawa diperkirakan hanya tinggal $10 \%$.Ini terjadi akibat perilaku masyarakat terhadap hutan mangrove yang tanpa batas seperti, mengkonversi lahan hutan mangrove menjadi berbagai peruntukan lain seperti tambak, pemukiman dan kawasan industri secara tidak terkendali, penebangan mangrove untuk arang, kayu bakar, bahan bangunan, pencemaran akibat buangan limbah minyak dari buangan kapal, industri dan samapah domestik rumah tangga, konflik kepentingan antar lembaga yaitu terjadinya perbedaan kepentingan antara pengelola hutan mangrove dengan pemerintah desa/ kecamatan, konflik kepentingan antar manfaat hutan mangrove: antara lain kepentingan ekonomi (economic) dan kepentingan pelestarian (enviromental), dan lain sebagainya. Begitu pula dengan kondisi hutan mangrove di Desa Pabean Ilir kondisinya saat ini sudah tergolong rusak tingkat sedang. Padahal mayoritas penduduk Desa Pabean ilir bermata pencaharian sebagai petani tambak, penggunaan lahan untuk pertanian tambak di Desa Pabean Ilir cukup dominan, ini dapat diperhatikan dari jumlah pemilik lahan tambak yang tiap tahun semakin bertambah. Kerusakan tersebut telah memberikan dampak merugikan bagi lingkungan maupun masyrakat, antara lain ditunjukan dengan semakin menurunya produktivitas hasil tambak, menurunnya tangkapan ikan, kesulitan air tawar karena intrusi air laut, meningkatnnya abrasi pantai, terjadinya kerusakan kawasan pemukiman oleh angin, badai, dan lain sebagainya. Hal ini disebabkan belum adanya kesadaran masyarakat akan keuntungan ganda yang bisa didapatkan jika mengusahakan perikanan di hutan mangrove serta akibat perbedaan persepsi dari masing-masing individu

\section{Rumusan Masalah}

Dalam penelitian ini yang menjadi rumusan masalahnya adalah : 1) Bagaimana kondisi Hutan Mangrove di Desa Pabean Ilir ? 2) Bagaimana kondisi sosial ekonomi masyarakat petani tambak di Desa Pabean Ilir? 3) Bagaimana persepsi masyarakat petani tambak terhadap kelestarian hutan Mangrove di Desa Pabean ilir?

\section{Tujuan dan Manfaat}

Tujuan yang ingin di capai dalam penelitian ini adalah sebagai berikut: 1) Mengidentifikasi kondisi hutan Mangrove di Desa Pabean Ilir; 2) Mengidentifikasi kondisi sosial ekonomi masyarakat petani tambak di Desa Pabean Ilir; 3) Mendeskripsikan persepsi masyarakat petani tambak terhadap kelestarian Hutan mangrove di Desa Pabean Ilir.

Penelitian diharapkan ini dapat bermanfaat : 1) Menjadi pertimbangan bagi pengambil kebijakan di Dinas Kehutanan Kabupaten Indramayu dalam rangka pemberdayaan hutan mangrove dan pelestariannya; 2) Memperluas khasanah pengetahuan bagi pengembangan lingkungan hidup dan pemberdayaan masyrakat pesisir; 3) Sebagai salah satu sumber data dan informasi bagi pengembangan penelitian di bidang geografi selanjutnya.

\section{METODE PENELITIAN}

Metode penelitian yang digunakan dalam penelitian ini adalah metode deskriptif dari hasil observasi lapangan, data-data sekunder yang terkait dan hasil wawancara dengan 
menggunakan angket. Adapun sampel dalam penelitian ini berjumlah 75 orang yang diambil secara purposive sampling.

\section{HASIL DAN PEMBAHASAN}

\section{Kondisi Fisik Daerah Penelitian}

Desa Pabean Ilir merupakan salah satu desa yang termasuk ke dalam wilayah Kecamatan Pasekan Kabupaten Indramayu. Secara administrasi Desa Pabean Ilir berbatasan dengan : sebelah utara dengan Laut Jawa; sebelah Timur dengan Desa Karanganyar; sebelah Selatan dengan Desa Berondong; sebelah Barat dengan Desa Totoran.

Lokasi Desa Pabean Ilir berada di sebelah Utara dari pusat administrasi Kecamatan Pasekan, jarak tempuh ke pusat Kecamatan Pasekan dari Desa Pabean Ilir $\pm 4 \mathrm{Km}$ dengan waktu tempuh \pm 15 menit dengan menggunakan kendaraan bermotor, jarak ke Ibu kota Kabupaten $\pm 7 \mathrm{Km}$ dengan waktu tempuh 30 menit dengan menggunakan kendaraan bermotor.

Secara astronomis Desa Pabean Ilir ini terletak pada $108^{\circ} .28^{\prime} 00^{\prime \prime}-108^{0} 17^{\prime} 9,6^{\prime \prime}$ BT dan $6^{0} .22^{\prime} .00^{\prime \prime}-6^{0} 14^{\prime} 14,12^{\prime \prime}$ LS. luas wilayah Desa Pabean Ilir pada tahun 2009 adalah 1.820.310 Ha, yang terdiri dari 20 RT dan 5 RW. .

Berdasarkan topografinya apabila dilihat dari peta Topografi Indramayu tahun 1999 lembar 1309-423 skala 1 : 25000 topografi Desa Pabean Ilir memilki bentukan bumi hampir semuannya dataran rendah. Desa Pabean Ilir terletak pada ketinggian 0-5 mdpl yang meliputi seluruh wilayah yakni $\pm 1.820 .310 \mathrm{Ha}$, sedangkan daerah Desa Pabean Ilir dilihat dari kemiringan lerengnya berkisar $0-5 \%$, dengan demikian Desa Pabean Ilir termasuk yang memilki relief relatif datar.

Konidisi iklim di Desa Pabean Ilir berdasrkan Perhitungan menggunakan rumus iklim Schmidt-Ferguson diperoleh nilai Q adalah 73.78 untuk menentukan ke dalam tipe mana angka tersebut, maka selanjutnya mencocokan dengan pengklasifikasian iklim SchmidtFerguson, berdasarkan kriteria iklim Schmidt-Ferguson iklim di Desa Pabean Ilir termasuk tipe D atau iklim Sedang.

\section{Penggunaan Lahan}

Berdasarkan data monografi lahan yang ada di Desa Pabean Ilir digunakan untuk berbagai peruntukan. Untuk lebih jelasnya dapat di lihat pada tabel 1.

Tabel 1. Penggunaan lahan di Desa Pabean Ilir

\begin{tabular}{llcc}
\hline No & \multicolumn{1}{c}{ Jenis Penggunaan Lahan } & Luas $(\mathrm{Ha})$ & $\%$ \\
\hline 1 & Tadah hujan & 308.250 & 16,94 \\
\hline 2 & Empang/ Tambak & 562,106 & 30,89 \\
\hline 3 & Permukiman & 264.172 & 14,52 \\
\hline 4 & Kebun & 317.832 & 17,47 \\
\hline 5 & Hutan/ rawa & 357.750 & 16,68 \\
\hline 6 & Jalan/ lainya & 10.200 & 0,58 \\
\hline & Jumlah & 1.820 .310 & 100
\end{tabular}

Sumber : Data Monografi Desa Pabean Ilir, 2009

\section{Kondisi Sosial Ekonomi Masyarakat}

Berdasarkan data monografi Desa Pabean Ilir tahun 2009, jumlah penduduk secara keseluruhan adalah 6.367 jiwa, terdiri dari 3.171 laki-laki dan 3.196 perempuan. Adapun 
Komposisi penduduk berdasarkan mata pencaharian memperlihatkan gambaran umum tentang orientasi ekonomi penduduk di Desa Pabean Ilir. Dapat di lihat pada tabel 2.

Tabel 2. Komposisi Penduduk Berdasarkan Mata Pencaharian

\begin{tabular}{llrc}
\hline No & \multicolumn{1}{c}{ Mata Pencaharian } & Jumlah & Prosentase (\%) \\
\hline 1 & Petani & 1790 & 28,12 \\
\hline 2 & Buruh tani & 2.039 & 32,03 \\
\hline 3 & swasta & 368 & 5,78 \\
\hline 4 & Pegawai Negeri & 70 & 1,20 \\
\hline 5 & Pedagang /wiraswasta & 1252 & 19,67 \\
\hline 6 & ABRI & 11 & 0,18 \\
\hline 7 & Pensiunan & 15 & 0,24 \\
\hline 8 & Nelayan & 4.59 & 0,08 \\
\hline 9 & Pemulung & 363 & 5,71 \\
\hline & Jumlah & 6.367 & 100 \\
\hline
\end{tabular}

Sumber : Data Monografi Desa Tahun 2009 dan Hasil perhitungan

\section{Kondisi Hutan Mangrove di Daerah Penelitian}

1. Letak dan luas hutan mangrove

Hutan mangrove di Desa Pabean Ilir Terletak di sepanjang pantai. Berdasarkan data dari Dinas Kehutanan Indramayu luas Hutan Mangrove di Desa Pabean Ilir adalah 367 Ha yang tersebar di sepanjang pantai untuk lebih jelasnya dapat dilhat pada peta penyebaran hutan Mangrove.

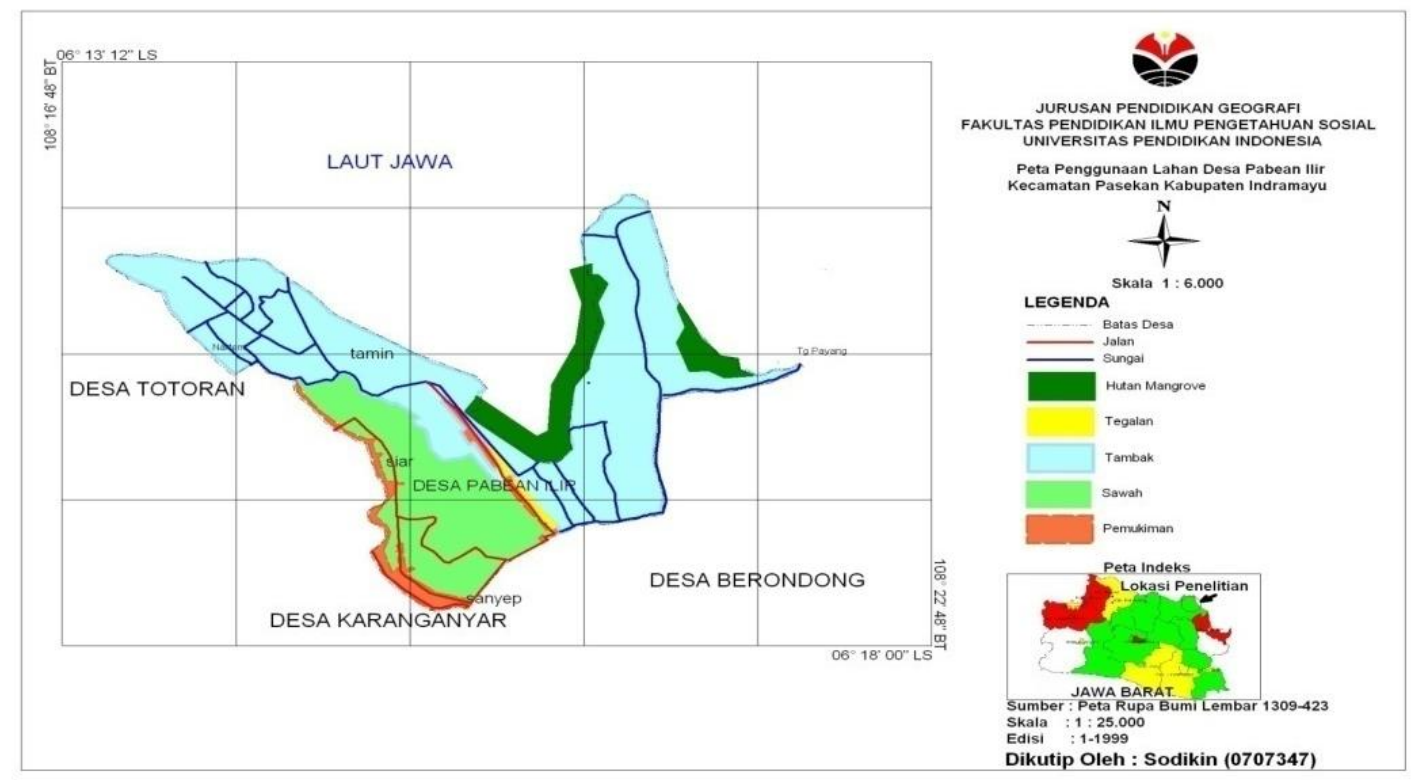

Gambar 1. Peta Penyebaran Hutan Mangrove di Desa Pabean Ilir

2. Jenis-jenis dan distribusi vegetasi mangrove di Desa Pabean Ilir

Berdasarkan hasil observasi di lapangan tercatat ada 10 jenis vegetasi mangrove dengan tiga jenis yang paling dominan di daerah penelitian yaitu rhizophora apiculata, rhizophora 
mucronata, dan Avicenia yang membentuk tegakan murni Adapun jenis-jenis mangrove yang di temukan pada saat observasi dapat dilihat di tabel 3.

Tabel 3. Jenis-jenis dan Distribusi Vegetasi Mangrove di Desa Pabean Ilir

\begin{tabular}{|c|c|c|c|c|c|}
\hline No & Spesies & Nama Daerah & Plot 1 & Plot 2 & Plot 3 \\
\hline 1 & Avicenia Marina & Api-api & $\sqrt{ }$ & $\sqrt{ }$ & $\sqrt{ }$ \\
\hline 2 & Avicennia alba & Api-api & $\sqrt{ }$ & $\sqrt{ }$ & $\sqrt{ }$ \\
\hline 3 & Nypa fruticans & Nipa & - & - & $\sqrt{ }$ \\
\hline 4 & Bruguiera parviflora & Tanjan & $\sqrt{ }$ & - & $\sqrt{ }$ \\
\hline 5 & Rhizhopora apiculata & Bakau Kacangan & $\sqrt{ }$ & $\sqrt{ }$ & $\sqrt{ }$ \\
\hline 6 & Rhizhopora mucronata & Bakau Gandul & $\sqrt{ }$ & $\sqrt{ }$ & $\sqrt{ }$ \\
\hline 7 & Rhizhopora stylosa & Lalora puith & $\sqrt{ }$ & - & $\sqrt{ }$ \\
\hline 8 & Soneratia & Pedada & $\sqrt{ }$ & - & - \\
\hline 9 & Corypha uton & Gebang & - & $\sqrt{ }$ & - \\
\hline 10 & Hibiscus tiliaceus & Waru & $\sqrt{ }$ & $\sqrt{ }$ & - \\
\hline
\end{tabular}

Ket : $\quad \sqrt{\text { : ditemukan; - : tidak ditemukan }}$

Sumber : Hasil Penelitian Lapangan, 2010

3. Hasil pengukuran diameter dan tinggi pohon mangrove pada lokasi penelitian

Berdasarkan hasil pengukuran di lapangan diameter dan tinggi pohon dapat di lihat pada tabel 4 .

Tabel 4. Hasil pengukuran diameter dan tinggi pohon mangrove pada lokasi penelitian

\begin{tabular}{|c|c|c|c|c|c|}
\hline \multirow[t]{2}{*}{ Spesies } & \multirow{2}{*}{\multicolumn{2}{|c|}{$\begin{array}{c}\text { Diameter, Tinggi, } \\
\text { Jumlah Anakan dan Remaja }\end{array}$}} & \multicolumn{3}{|c|}{ PLOT } \\
\hline & & & Plot I & Plot II & Plot III \\
\hline \multirow{2}{*}{ Avicenia Marina } & $>$ & Rentang diameter $(\mathrm{cm})$ & $15-25$ & $7-10$ & $15-20$ \\
\hline & $>$ & Rentang tinggi $(\mathrm{m})$ & $4-6$ & $3-5$ & $5-10$ \\
\hline \multirow{2}{*}{ Avicennia alba } & $>$ & Rentang diameter $(\mathrm{cm})$ & $10-15$ & - & $7-15$ \\
\hline & $D$ & Rentang tinggi $(\mathrm{m})$ & $2-10$ & - & \\
\hline \multirow[t]{2}{*}{ B. parviflora } & 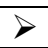 & Rentang diameter $(\mathrm{cm})$ & $7-10$ & - & $5-7$ \\
\hline & $>$ & Rentang tinggi $(\mathrm{m})$ & $5-10$ & - & $2-7$ \\
\hline \multirow[t]{2}{*}{ R. apiculata } & $>$ & Rentang diameter $(\mathrm{cm})$ & $0,5-3$ & $1-2$ & $0,5-3$ \\
\hline & $>$ & Rentang tinggi $(\mathrm{m})$ & $5-7$ & $4-6$ & $3-5$ \\
\hline \multirow[t]{2}{*}{ R. mucronata } & $>$ & Rentang diameter $(\mathrm{cm})$ & $0,5-3$ & $0,5-2$ & $0,5-3$ \\
\hline & $>$ & Rentang tinggi (m) & $4-6$ & $4-6$ & $3-5$ \\
\hline \multirow[t]{2}{*}{ R.stylosa } & $>$ & Rentang diameter $(\mathrm{cm})$ & $0,5-3$ & - & $0,5-4$ \\
\hline & $\nabla$ & Rentang tinggi $(\mathrm{m})$ & $2-6$ & - & $2-5$ \\
\hline \multirow[t]{2}{*}{ Nypa fruticans } & $>$ & Rentang diameter $(\mathrm{cm})$ & - & - & $0,5-2$ \\
\hline & $>$ & Rentang tinggi $(\mathrm{m})$ & - & - & $4-6$ \\
\hline \multirow[t]{2}{*}{ Soneratia } & $>$ & Rentang diameter $(\mathrm{cm})$ & $3-6$ & - & - \\
\hline & $D$ & Rentang tinggi (m) & $5-10$ & - & - \\
\hline \multirow[t]{2}{*}{ Corypha uton } & $>$ & Rentang diameter $(\mathrm{cm})$ & - & $2-3$ & - \\
\hline & $>$ & Rentang tinggi $(\mathrm{m})$ & - & $2-3$ & - \\
\hline \multirow[t]{2}{*}{ Hibiscustiliaceus } & $>$ & Rentang diameter $(\mathrm{cm})$ & $5-10$ & $5-10$ & - \\
\hline & $>$ & Rentang tinggi (m) & $7-10$ & $10-15$ & - \\
\hline
\end{tabular}

Sumber : Hasil Penelitian Lapangan, 2010

\section{Fauna Hutan Mangrove di Desa Pabean Ilir}

Fauna yang terdapat di hutan mangrove Desa Pabean Ilir berdasarkan hasil observasi terdapat berbagai macam fauna baik fauna darat maupun fauna air ini dapat di bisa dilihat di Tabel 5. 
Tabel 5. Jenis Fauna Hutan Mangrove di Desa Pabean Ilir

\begin{tabular}{llll}
\hline No & Binatang Darat & Binatang Air & Binatang Unggas \\
\hline 1 & Biawak & Ikan Glodog & Crockok \\
\hline 2 & Kupu-kupu & Udang & Alap-alap \\
\hline 3 & Capung & Ikan Blanak & Cici \\
\hline 4 & Belalang & Mujaer & Dadali \\
\hline 5 & Tikus & & \\
\hline
\end{tabular}

Sumber :hasil penelitian Lapangan 2010

\section{Persepsi Masyarakat Petani Tambak terhadap Kelestarian Hutan Mangrove}

1. Persepsi petani tambak terhadap dampak pemanfaatan hutan mangrove terhadap lingkungan

Hasil wawancara di lapangan mengenai persepsi petani tambak terhadap dampak pemanfaatan hutan mangrove terhadap lingkungan di Desa Pabean Ilir dapat dilihat pada tabel 5 .

Tabel 5. Persepsi Petani Tambak terhadap Dampak Pemanfaatan Hutan Mangrove terhadap Lingkungan di Desa Pabean Ilir

\begin{tabular}{cccc}
\hline No & Parameter & F & $\%$ \\
\hline 1 & Merusak lingkungan & 37 & 49,3 \\
\hline 2 & Tidak Merusak lingkungan & 38 & 50,7 \\
\hline & Jumlah & 75 & 100 \\
\hline
\end{tabular}

Sumber : Hasil Penelitian Lapangan, 2010

Berdasarkan tabel 5 di atas dapat dilihat bahwa responden 49,3\% mempunyai persepsi bahwa pemanfaatan hutan mangrove dapat merusak lingkungan dan 50,7\% responden mempunyai persepsi pemanfaatan hutan mangrove tidak merusak lingkungan. Jadi secara umum masyarakat petani tambak di Desa Pabean Ilir mempunyai persepsi bahwa pemanfaatan hutan mangrove tidak merusak lingkungan.

2. Persepsi petani tambak terhadap Manfaat Kelestarian Hutan Mangrove Secara Ekonomi

Hasil wawancara di lapangan mengenai persepsi petani tambak terhadap manfaat kelestarian secara ekonomi hutan mangrove di Desa Pabean Ilir dapat dilihat pada tabel 6.

Tabel 6. Persepsi Petani Tambak terhadap Manfaat Kelestarian Hutan Mangrove secara Ekonomi

\begin{tabular}{|c|c|c|c|}
\hline \multirow{2}{*}{ No } & \multirow{2}{*}{ Parameter } & \multicolumn{2}{|c|}{ Responden } \\
\hline & & $\mathrm{F}$ & $(\%)$ \\
\hline \multirow[t]{6}{*}{1} & Sangat bermanfaat & & \\
\hline & Alasan : & & \\
\hline & $>$ Tempat mencari kayu bakar & 27 & 36 \\
\hline & $>$ kayu hutan mangrove untuk dijual & 5 & 6,7 \\
\hline & $>$ Tempat untuk mencari ikan dan kepiting & 37 & 49,3 \\
\hline & $>$ Sebagai bahan baku makanan & 4 & 5,3 \\
\hline \multirow[t]{4}{*}{2} & Tidak bermanfaat & & \\
\hline & Alasan : & & \\
\hline & $>$ Tidak ada yang bisa dimanfaatkan & 2 & 2,7 \\
\hline & Jumlah & 75 & 100 \\
\hline
\end{tabular}

Sumber : Hasil Penelitian Lapangan, 2011 
Berdasarkan tabel 6, dapat dilihat bahwa responden $36 \%$ persepsi bahwa kelestarian hutan mangrove sangat bermanfaat secara ekonomi untuk tempat mencari kayu bakar, 6,7\% kayu hutan mangrove untuk dijual, 49,3\% tempat mencari ikan dan kepiting, 5,3\% sebagai bahan baku makanan dan $2,7 \%$ responden mempunyai persepsi bahwa kelestarian hutan mangrove secara ekonomi tidak bermanfaat. Jadi secara umum masyarakat petani tambak di Desa Pabean Ilir setengahnya mempunyai persepsi bahwa kelestarian hutan mangrove secara ekonomi sangat bermanfaat untuk tempat mencari ikan dan kepiting.

3. Persepsi petani tambak terhadap kelestarian hutan mangrove secara teknis

Hasil wawancara di lapangan mengenai persepsi petani tambak terhadap manfaat kelestarian hutan mangrove secara teknis di Desa Pabean Ilir dapat dilihat pada tabel 7.

Tabel 7. Persepsi Petani Tambak Terhadap Manfaat Kelestarian Hutan Mangrove Secara Teknis Di Desa Pabean Ilir

\begin{tabular}{|c|c|c|c|}
\hline \multirow{2}{*}{ No } & \multirow{2}{*}{ Parameter } & \multicolumn{2}{|c|}{ Responden } \\
\hline & & $\mathrm{F}$ & $(\%)$ \\
\hline \multirow[t]{5}{*}{1} & Sangat bermanfaat & & \\
\hline & Alasan: & & \\
\hline & $>$ Mencegah terjadinya abrasi & 65 & 86,6 \\
\hline & $>$ Mengurangi ombak dan volume air pantai & 5 & 6,7 \\
\hline & $>$ Sebagai paru-paru untuk masyrakat pantai & 5 & 6,7 \\
\hline \multirow[t]{4}{*}{2} & Tidak bermanfaat & & \\
\hline & Alasan: & & \\
\hline & $>$ Tidak ada yang bisa dimanfaatkan & 0 & 0,0 \\
\hline & Jumlah & 75 & 100 \\
\hline
\end{tabular}

Sumber : Hasil Penelitian Lapangan, 2010

Berdasarkan tabel 7, bahwa responden 86,6 \% mempunyai persepsi bahwa kelestarian hutan mangrove sangat bermanfaat secara teknis untuk mencegah terjadinya abrasi, 6,7\% untuk mengurangi ombak, dan 6,7\% sebagai paru-paru masyarakat pantai. Jadi sebagian besar masyarakat petani tambak di Desa Pabean Ilir mempunyai persepsi bahwa kelestarian hutan mangrove secara teknis sangat bermanfaat untuk mencegah terjadinya abrasi.

\section{Persepsi Petani Tambak Terhadap Kelestarian Hutan Mangrove Secara Sosial}

Hasil wawancara di lapangan mengenai persepsi petani tambak terhadap manfaat kelestarian secara sosial hutan mangrove di Desa Pabean Ilir dapat dilihat pada tabel 8.

Tabel 8. Persepsi Petani Tambak Terhadap Manfaat Kelestarian Hutan Mangrove Secara Sosial Di Desa Pabean Ilir

\begin{tabular}{llrr}
\hline \multirow{2}{*}{ No } & \multicolumn{1}{c}{ Parameter } & \multicolumn{2}{c}{ Responden } \\
\cline { 3 - 4 } & & $\mathrm{F}$ & $(\%)$ \\
\hline 1 & Sangat bermanfaat & & \\
& Alasan : & 33 & 44 \\
& $>\quad$ Mengurangi Pengangguran & 40 & 53,3 \\
\hline & $>$ Menambah keindahan pemandangan & & \\
\hline 2 & Tidak bermanfaat & 2 & 2,7 \\
& Alasan : & 75 & 100 \\
\hline & $>\quad$ Tidak ada yang bisa dimanfaatkan & & \\
\hline
\end{tabular}


Sumber : Hasil Penelitian Lapangan, 2010

Berdasarkan tabel 8, bahwa responden $44 \%$ mempunyai persepsi bahwa kelestarian hutan mangrove sangat bermanfaat secara sosial untuk mengurangi pengangguran, 53,3\% untuk menambah keindahan pemandangan, dan $2,7 \%$ responden mempunyai persepsi bahwa kelestarian hutan hutan mangrove secara sosial tidak bermanfaat. Jadi secara umum masyarakat petani tambak di Desa Pabean Ilir mempunyai persepsi bahwa kelestarian hutan mangrove secara sosial sangat bermanfaat untuk menambah keindahan pemandangan.

\section{SIMPULAN}

Desa Pabean Ilir adalaha salah satu desa yang berada di Kecamatan Pasekan yang memiliki topografi dataran rendah yaitu terletak pada ketinggian 0-5 mdpl, berdasarkan klasifikasi iklim Schmidt-Ferguson iklim di daerah penelitian adalah tipe D (iklim sedang). Jumlah penduduk di Desa Pabean Ilir adalah 6.367 jiwa dan mayoritas memiliki mata pencaharian sebagai petani dan buruh tambak. Hutan Mangrove di Desa Pabean Ilir terletak di sepanjang pantai dan memiliki luas $367 \mathrm{Ha}$, jenis vegetasi yang paling dominan yaitu Rhizophora apicullata, Rhizophora mucronata, dan Avicenia, tingkat kerapatan tergolong cukup rapat, ini terlihat dari jarak tanam antar pohonnya yaitu $30-40 \mathrm{~cm}$ dan tinggi pohon rata-rata $200 \mathrm{~cm}$ dengan kanopi yang cukup lebar, adapun jenis faunanya antara lain ikan Gelodok, kepiting, biawak, berbagai jenis burung, udang, dan sebagainya. Vegetasi mangrove tumbuh dengan optimal karena faktor fisik di daerah tersebut sesuai untuk pertumbuhan vegetasi mangrove.

Persepsi masyarakat Desa Pabean Ilir terhadap manfaat kelestarian hutan mangrove secara ekonomi masyarakat memandang sangat bermanfaat untuk tempat mencari ikan dan kepiting, secara teknis bermanfaat untuk mencegah terjadinya abrasi, sedangkan dari segi sosial masyarakat mempunyai persepsi bahwa hutan mangrove sangat bermanfaat untuk menambah keindahan pemandangan.

Berdasarkan hasil kesimpulan temuan dari penelitian ini, maka penulis mencoba untuk memberikan saran dan semoga bermanfaat bagi pihak-pihak terkait dalam penenlitian ini, yaitu 1) Bagi masyarakat yang tinggal di kawasan hutan mangrove, penulis berharap agar dapat meningkatkan kembali kesadaran akan lingkungan sekitarnya yaitu ikut berpartisipasi dalam upaya kelestarian hutan mangrove; 2) Kerjasama antara masyarakat dengan pemerintah setempat perlu ditingkatkan untuk lebih mengembangkan upaya kelestarian hutan mangrove di Desa Pabean Ilir; 3) Perlu adanya peningkatan intensitas penyuluhan dari dinas kehutanan maupun LSM setempat agar masyarakat memiliki pemahaman yang lebih luas mengenai manfaat dari hutan mangrove.

\section{DAFTAR PUSTAKA}

Anonim. (2006). Udang DiBalik Mangrove. www.dephut.go.id

Arief, A. (1994). Hutan, Hakekat, dan Pengaruhnya Terhadap Lingkungan. Jakarta: Yayasan Obor Indonesia.

Dahuri, Rokhmin dkk. (1996). Penglolaan Sumber daya Wilayah Pesisir dan Lautan Secara

Terpadu. Jakarta : PT Pradnya Paramita.

Data Monografi Desa Pabean Ilir tahun 2009.

Donanti, Patria. (2002), Penglolaan Hutan Mangrove di Segara Anakan. Bandung: Skripsi 
Pendidikan Georafi UPI.

Perum Perhutani. (1991). Penerapan Strategi Perhutanan Sosial Hutan Payau (Silvo Fishery) Perum Perhutani Menunjang Produksi Pangan Nasional. Bandung: Perum Perhutani Unit III Jawa Barat.

Tisnasomantri, Akub. (1998). Geomorfologi Umum Jilid I . Bandung: Jurusan Pendidikan Geografi FKIP-IKIP Bandung.

Rafi'i, Suryatna. (1985). Meteorologi dan Klimatologi. Bandung: Angkasa.

Savitri, Laksmi A dan Kazali M.(1999). Perbedayaan Masyarakat Dalam Penglolaan Wilayah Pesisir . Bogor :Pusat Kajian Sumber Daya Pesisir dan Lautan IPB

Tim Penyusun Pedoman Umum Direktorat Bina Pesisir. (2004). Pedoman Penglolaan Ekosistem Mangrove. Departemen Kelautan dan Perikanan Direktorat Jenderal Pesisir dan Pulau-pulau kecil Direktorat Bina Pesisir, Pesisir, Jakarta 